\title{
Article \\ Evaluation of Antioxidant and Anticorrosive Activities of Ceriops tagal Plant Extract
}

\author{
Md Shamsuzzaman ${ }^{1,2}$, Kathirvel Kalaiselvi ${ }^{3}$ and Mayakrishnan Prabakaran ${ }^{2, *}$ \\ 1 Department of Pharmacy, Stamford University Bangladesh, Dhaka 1217, Bangladesh; \\ shamsuzzamanbph@gmail.com \\ 2 Department of Crop Science, College of Sanghuh Life Science, Konkuk University, Seoul 05029, Korea \\ 3 Department of Chemistry, J.K.K. Nataraja College of Arts and Science, Namakkal 638 183, Tamil Nadu, India; \\ Kalaiselvi_k@jkkn.ac.in \\ * Correspondence: prabakaran@konkuk.ac.kr
}

check for updates

Citation: Shamsuzzaman, M.; Kalaiselvi, K.; Prabakaran, M. Evaluation of Antioxidant and Anticorrosive Activities of Ceriops tagal Plant Extract. Appl. Sci. 2021, 11, 10150. https://doi.org/10.3390/ app112110150

Academic Editor: Monica Gallo

Received: 25 August 2021

Accepted: 23 October 2021

Published: 29 October 2021

Publisher's Note: MDPI stays neutral with regard to jurisdictional claims in published maps and institutional affiliations.

Copyright: (C) 2021 by the authors. Licensee MDPI, Basel, Switzerland. This article is an open access article distributed under the terms and conditions of the Creative Commons Attribution (CC BY) license (https:// creativecommons.org/licenses/by/ $4.0 /)$.

\begin{abstract}
Mangroves are plants known for their various medicinal and economical values, and therefore are widely investigated for their phytochemical, antioxidant, antidiarrheal, and antimicrobial activities. In the present study, we analyze the antioxidant and anticorrosive properties of Ceriops tagal (C. tagal), a tropical and subtropical mangrove plant of the Rhizophoraceae family. The total phenolic content (TPC) and total flavonoid content (TFC) were found to be 101.52 and $35.71 \mathrm{mg} / \mathrm{g}$, respectively. The extract $(100 \mu \mathrm{g} / \mathrm{mL})$ exhibited $83.88,85$, and $87 \%$ antioxidant property against 1,1-diphenyl-2-picrylhydrazyl (DPPH), nitric oxide, and hydrogen peroxide free radicals. In addition, $600 \mathrm{ppm}$ of $C$. tagal extract showed 95\% corrosion inhibition against $1 \mathrm{M} \mathrm{HCl}$ attack on mild steel at $303 \pm 1 \mathrm{~K}$, which declined over other concentrations and temperatures, where AAS produced $82 \%$ inhibition at $600 \mathrm{ppm}$. UV-visible spectroscopy analysis revealed the formation of an inhibitor metal complex. The elemental analysis provided the presence of $84.21,9.01$, and $6.37 \%$ of $\mathrm{Fe}, \mathrm{O}$, and C, respectively, in inhibited mild steel, whereas the same were 71.54, 22.1, and 4.34\%, respectively, in uninhibited specimen, stressing the presence of protective film on the metal surface. Scanning electron microscopy (SEM) also showed some noteworthy changes in both uninhibited and inhibited mild steel, making C. tagal plant a better alternative than any other synthetic inhibitors. Further, the atomic force microscopy (AFM) surface topography analysis showed that $600 \mathrm{ppm}$ of $C$. tagal extract significantly diminished corrosion on the surface of mild steel.
\end{abstract}

Keywords: Ceriops tagal; antioxidant; corrosion inhibition; mild steel; SEM-EDX; AFM

\section{Introduction}

Mangroves are woody halophytic plants covering about $160,000 \mathrm{~km}^{2}$ all over the world. Mangroves adapt to anoxic soil and salt stress conditions inhabiting several exclusive plant species that are limited to mangrove vegetation. Mangroves are prevalent in upper intertidal zones of brackish or saline water, coastal regions of Asia (India, Indonesia, Bangladesh, and Malaysia), Africa (Nigeria and Madagascar), Australia, Brazil, Mexico, the Caribbean Sea, and the Western Atlantic Ocean [1-3]. Mangroves plants are recognized as economically valuable as they are utilized in medicines, agriculture, firewood, charcoal, and wood productions [4]. They act as a key factor in blocking tsunami and cyclones, whereas mangrove wetlands serve as a breeding place for migratory birds and fishes [5]. Many mangrove plants have traditionally been used to treat plant, animal, and human pathogens. These are plants with significant secondary metabolites of remarkable global importance. Components, specifically, alkaloids, saponins, amino acids, phenols, flavonoids, polyunsaturated fatty acids, carbohydrates, quinines, terpenes, tannins, and steroids, have been identified in numerous mangroves [6]. To be precise, pentanoic and propanoic acids, acetamide, diethylhydroxylamine (DEHA), pyrrolidine (tetrahydropyrrole), and 4-thiadiazole derivatives (ethylene oxide and 2-dimethyl-propanesulfinyl sulfone) have 
been reported as food additives, anti-atherosclerotic, antioxidant, anti-ageing, antitumor, anti-cholinergic, antimicrobial, analgesic, and anti-inflammatory agents from Avicennia marina (Forssk.) Vierh [7].

Apart from this, plants such as Laguncularia racemosa L., metformin from Galega officinalis L., Avicennia germinans L., Bruguiera gymnorhiza L., Rhizophora mucronate, and Rhizophora mangle are often used as insecticides and protein kinase inhibitor, anticancer, anti-ulcer, anti-inflammatory, antidiabetic, antioxidant, analgesic, anti-cholinesterase, antihemorrhage, antimicrobial, and wound healing products [8-10]. In addition to the plants, microbes associated with mangroves, for instance, Codium fragile, halophilic bacteria, actinomycete, and Nocardia sp., have been recognized as powerful anticoagulant, polyketide synthases (resveratrol, erythromycin, and lovastatin), anti-infection, and 2-pyronone derivatives [11]. In addition to the biological activities, plant compounds have been established as excellent corrosion inhibitors against aggressive mediums (acid and alkaline solutions) to protect metals and alloys replacing other inorganic and synthetic inhibitors as they are expensive and have proven to be toxic to the environment and humans. Interest in green inhibitors has consistently increased since 1950, which has majorly focused on plants extract and other plant-derived compounds as corrosion inhibitors. To name a few, R-(+)-pulegone from pennyroyal oil (Mentha pulegium), Aloe vera, Mangifera indica, natural polymers (mimosa tannin and guar gum), model green inhibitors (tryptophan and glutamic acid), allyl propyl disulfide (garlic), alkaloid berberine (mustard seeds), monomtrene 1,8-cineole (Eucalyptus oil), amines and bioflavonoids (Garcinia kola), and flavonoids, amino acids, and pigments (calyx extract) have been identified as effective corrosion inhibitors [12,13]. There is evidence that explains the role of double or triple bonded heteroatoms and highdensity electrons such as oxygen, sulfur, phosphorus, and nitrogen in organic compounds in inhibiting corrosion through their impressive adsorption tendency [14]. Reports have even mentioned the inhibition efficiency of sulfur atoms in cysteine (-SH) and methionine $\left(-\mathrm{S}-\mathrm{CH}_{3}\right)$ as major factors that increase the anticorrosive nature as compared with other amino acids without sulfur group [15].

Though many plants of tropical regions have been put forward as green inhibitors, mangroves are less known in the field of corrosion. Therefore, in this study, efforts were made to identify the capability of Ceriops tagal (C. tagal), a salt-tolerant mangrove tree, for its antioxidant and anticorrosion properties. C. tagal belongs to the family of Rhizophoraceae and is predominant in tropical or subtropical areas [16]; $\alpha$-amyrin, lupeol, triterpenoids, tannins, triterpenes, phenylproponoids, dolabranes, and several other constituents isolated from C. decandra and C. tagal are widely accepted as antifungal, antitumor, anti-larval, antimalarial, antifeedant, antidiabetic, anti-hemorrhage, antifouling, and antifeedant compounds [17-19]. In 2018, various new components, such as shown in Figure 1 (tagalphenylpropanoidins A, tagalphenylpropanoidins $\mathrm{B}$, and 2,3,6-trimethoxy-5-(1-propenyl) phenol), from stems and twigs of $C$. tagal were identified [20]. 
$\mathbf{a}$<smiles>COC(=O)/C=C/c1cc(OC)c(OC)c(O)c1OC</smiles>

b<smiles>C/C=C/c1cc(OC)c(OC)c(O)c1OC</smiles><smiles>COC(=O)/C=C\c1cc(OC)c(OC)c(O)c1OC</smiles>

Figure 1. Chemical statures of: (a) Tagalphenylpropanoidins A; (b) tagalphenylpropanoidins B; (c) 2,3,6-trimethoxy-5-(1-propenyl) phenol.

In addition to these, Cladosporium sp. HNWSW-1 and Cladosporium sp. JJM22, two endophytic fungi strains from $C$. tagal, have also been found to produce succinimide, ribofuranose phenol, and naphthalene derivatives [21,22]. In this study, efforts were made to find out the biological and anticorrosive effects of $C$. tagal. In the case of mild steel corrosion against $1 \mathrm{M} \mathrm{HCl}$, weight loss measurements, UV-visible, atomic adsorption spectrometric (AAS), and scanning electron microscopy (SEM) energy dispersive spectroscopy (EDX) were performed. Additionally, the surface topography of mild steel was analyzed by atomic force microscopy (AFM) and scanning electron microscopy (SEM).

\section{Materials and Methods}

\subsection{Metal Preparation}

Mild steel with $0.091 \%$ C, $0.021 \% \mathrm{P}, 0.022 \% \mathrm{~S}, 0.21 \% \mathrm{Mn}, 0.39 \% \mathrm{Mg}$, and the remaining made of Fe was selected. The mild steel coupon of size $3 \times 1 \times 0.5 \mathrm{~cm}$ was reserved for weight loss and surface analyses [23]. The same composition of mild steel rod with $0.785 \mathrm{~cm}^{2}$ exposed area was used for the spectrophotometric analysis. The specimens were abraded using $1 / 0,2 / 0,3 / 0$, and $4 / 0$ emery sheets and washed with double distilled water. Acetone was utilized to degrease the specimens, and later they were dried and stored alongside desiccator to prevent moisture. The corrodent solution $(1 \mathrm{M} \mathrm{HCl})$ was prepared by dissolving analar grade hydrochloric acid in double distilled water. All experiments were repeated three times to ensure accurate results.

\subsection{Plant Extract Preparation}

The C. tagal leaves were collected from Tamil Nadu, India. They were washed in running tap water to remove sand, dust, and other unwanted materials [23], and then shade dried for a few days and made into fine powder. To $300 \mathrm{~g}$ of plant material, $5 \mathrm{~L}$ of methanol was added and left as such for 5 days at room temperature (RT) $303 \pm 1 \mathrm{~K}$. The solvent was changed every $24 \mathrm{~h}$ for thorough extraction. Whatman grade 1 filter paper with $11 \mu \mathrm{m}$ (particle retention) pores was used to filter the mixture. A rotatory evaporator was used to evaporate excess solvent leaving pure extract, and we obtained $112.5 \mathrm{~g}$ of plant 
extract. To prepare the different concentrations $(100,200,300,400,500$, and $600 \mathrm{ppm})$ of plant extract, a known amount of extract was diluted in $1 \mathrm{M} \mathrm{HCl}$, and this was used for corrosion studies.

\subsection{Total Phenolic Content (TPC) and Total Flavonoid Content Analysis}

The TPC estimation was performed using a previously described method with slight modification [24]. For TPC, $3.16 \mathrm{~mL}$ of distilled water was mixed with $40 \mu \mathrm{L}$ of $C$. tagal extract. To this, $200 \mu \mathrm{L}$ of Folin-Ciocalteu (FC) reagent and $600 \mu \mathrm{L}$ of $20 \%$ sodium carbonate were added and kept at RT ( $303 \pm 1 \mathrm{~K})$ for $2 \mathrm{~h}$. After incubation, absorbance was read at $765 \mathrm{~nm}$ in a Mecasys Optizen 2120 UV plus UV-spectrophotometer (Mecasys, Korea) against blank. The readings were calculated using gallic acid standard curve and the values (in $\mathrm{mg} / \mathrm{g}$ ) were expressed as gallic acid equivalent (GAE). For TFC, $0.5 \mathrm{~mL}$ of $100 \mathrm{mg} / \mathrm{mL}$ C. tagal extract, $0.1 \mathrm{~mL}$ of $1 \mathrm{M}$ potassium acetate and $10 \%$ aluminum chloride, and $4.3 \mathrm{~mL}$ of distilled water were mixed together [25]. This mixture was incubated for $30 \mathrm{~min}$ at RT ( $303 \pm 1 \mathrm{~K}$ ) and absorbance was read at $415 \mathrm{~nm}$ using a Mecasys Optizen 2120 UV plus UV-spectrophotometer (Mecasys, Korea). The final values were expressed in quercetin equivalents.

\subsection{Antioxidant Studies}

The antioxidant activity of plant extract was carried out by examining the free radical scavenging (1,1-diphenyl-2-picrylhydrazyl (DPPH), nitric oxide, and hydrogen peroxide), reducing potential, and total antioxidant capacity assays, with slight modifications [26,27]. The final values were determined by using ascorbic acid as the standard for each of these assays.

\subsubsection{DPPH Free-Radical Scavenging Assay}

For the DPPH free-radical scavenging assay, $0.2 \mathrm{~mL}$ of $10-100 \mu \mathrm{g} / \mathrm{mL}$ C. tagal extract was mixed with $2 \mathrm{~mL}$ of $0.5 \mathrm{mM}$ 1,1-diphenyl-2-picrylhydrazyl (DPPH) prepared in methanol. With this, a blank containing only methanol was prepared. These were kept in the dark for $30 \mathrm{~min}$. Absorbance was measured for test samples against a blank at $517 \mathrm{~nm}$ and the percentage of free radical scavenged was calculated using the following equation:

$$
\text { Inhibition of DPPH radical }(\%)=\left(\mathrm{A}_{\text {control }}-\mathrm{A}_{\text {sample }}\right) / \mathrm{A}_{\text {control }} \times 100
$$

Here, control absorbance, i.e., DPPH without sample is denoted as $\mathrm{A}_{\text {control }}$ and sample with DPPH as $\mathrm{A}_{\text {sample. }}$

\subsubsection{Nitric Oxide Inhibition}

For the nitric oxide inhibition assay, $2 \mathrm{~mL}$ of $10 \mathrm{mM}$ sodium nitroprusside, $0.5 \mathrm{~mL}$ of phosphate saline ( $\mathrm{pH} 7.4$ ), and $0.5 \mathrm{~mL}$ of (each concentration, $100-1000 \mu \mathrm{g} / \mathrm{mL}$ ) C. tagal sample were put in a test tube and incubated at $298 \pm 1 \mathrm{~K}$ for $2 \mathrm{~h}$. After incubation, $0.5 \mathrm{~mL}$ of Griess reagent prepared using $2 \%$ phosphoric acid, $1 \%$ of sulfanilic acid, and $0.1 \%$ naphthylethylenediamine dichloride was mixed and incubated at RT ( $303 \pm 1 \mathrm{~K})$ for $30 \mathrm{~min}$. The percentage of nitric oxide inhibited by plant extract was calculated using the following equation after measuring the absorbance at $546 \mathrm{~nm}$ :

$$
\text { Nitric oxide inhibited }(\%)=\left(\mathrm{A}_{\text {control }}-\mathrm{A}_{\text {sample }}\right) / \mathrm{A}_{\text {control }} \times 100
$$

Here, reaction solution leaving test sample is denoted as $A_{\text {control }}$ and sample with reaction mixture as $A_{\text {sample. }}$.

\subsubsection{Hydrogen Peroxide Free-Radical Scavenging}

For hydrogen peroxide free-radical scavenging, $1 \mathrm{~mL}$ of $40 \mathrm{mM}$ hydrogen peroxide was prepared using phosphate buffer ( $\mathrm{pH}$ 7.4). To this, different concentrations $(100-1000 \mu \mathrm{g} / \mathrm{mL})$ of $C$. tagal extracts were mixed well. The same was followed with- 
out adding extract for preparing the blank. All of these prepared solutions, i.e., samples and blank were kept as such for $10 \mathrm{~min}$. Hydrogen peroxide scavenging activity was determined by reading the absorbance at $230 \mathrm{~nm}$ and using the following equation:

$$
\text { Hydrogen peroxide scavenged }(\%)=\left(\mathrm{A}_{\text {control }}-\mathrm{A}_{\text {sample }}\right) / \mathrm{A}_{\text {control }} \times 100
$$

Here, control absorbance, i.e., phosphate buffer without hydrogen peroxide is denoted as $\mathrm{A}_{\text {control }}$ and sample with hydrogen peroxide as $\mathrm{A}_{\text {sample }}$.

\subsubsection{Reducing Potential}

In $1.0 \mathrm{~mL}$ (each concentration, $50-500 \mu \mathrm{g} / \mathrm{mL}$ ) of $C$. tagal sample dissolved in distilled water, $2.5 \mathrm{~mL}$ of $0.2 \mathrm{M}$ phosphate buffer $(\mathrm{pH} 6.6)$, and $2.5 \mathrm{~mL}$ of $1 \%(w / v)$ potassium ferricyanide were mixed together and incubated at $323 \pm 1 \mathrm{~K}$ for $20 \mathrm{~min}$. Then, $2.5 \mathrm{~mL}$ of $10 \%$ trichloroacetic acid was added and centrifuged at $3000 \mathrm{rpm}$ for $10 \mathrm{~min}$. From this, $2.5 \mathrm{~mL}$ of upper layer was dropped in $2.5 \mathrm{~mL}$ of distilled water and $0.5 \mathrm{~mL}$ of $0.1 \%(w / v)$ ferric chloride to measure the absorbance at $700 \mathrm{~nm}$.

\subsubsection{Phosphomolybdate Method}

One milliliter of reagent containing $4 \mathrm{mM}$ ammonium molybdate, $28 \mathrm{mM}$ sodium phosphate, and $0.6 \mathrm{M}$ sulfuric acid was mixed with $0.1 \mathrm{~mL}$ of $100 \mu \mathrm{g} \mathrm{C}$. tagal sample. The mixture was kept tightly caped at $368 \pm 1 \mathrm{~K}$ for $90 \mathrm{~min}$ in a boiling water bath. After incubation, it was thoroughly cooled to RT ( $303 \pm 1 \mathrm{~K}$ ) and read at $695 \mathrm{~nm}$ against the blank that consisted of solvent and reagent solution.

$$
\text { Total antioxidant capacity }(\%)=\left(\mathrm{A}_{\text {control }}-\mathrm{A}_{\text {sample }}\right) / \mathrm{A}_{\text {control }} \times 100
$$

Here, $\mathrm{A}_{\text {control }}$ represents a blank whereas $\mathrm{A}_{\text {sample }}$ represents a sample with reagent.

\subsection{Corrosion Inhibition}

\subsubsection{Weight Loss Method}

For finding the exact condition preventing corrosion in mild steel against $1 \mathrm{M} \mathrm{HCl}$, weight loss methods in two different parameters (concentration and temperature) were examined. The percentage of inhibition efficiency $(\eta \%)$ and surface coverage $(\theta)$ were calculated individually for both the parameters using the following equations [28-30]:

$$
\begin{gathered}
\text { Inhibition efficiency }(\eta \%)=\left(\mathrm{W}_{0}-\mathrm{W}_{\mathrm{i}} / \mathrm{W}_{0}\right) \times 100 \\
\text { Surface coverage }=(\theta)=\frac{\eta(\%)}{100}
\end{gathered}
$$

where $\mathrm{W}_{0}$ and $\mathrm{W}_{\mathrm{i}}$ are the weight loss of the mild steel in the absence and the presence of the inhibitor, respectively.

\section{Effect of Concentration on Corrosion Inhibition}

The percentage inhibition efficiency $(\eta \%)$ and surface coverage $(\theta)$ of the plant extract were recognized by the difference between the initial and after weight of mild steel immersed in corrodent solution. The mild steel specimens were immersed in $1 \mathrm{M} \mathrm{HCl}$ without and with different concentrations $(100,200,300,400,500$, and $600 \mathrm{ppm})$ of inhibitor at $303 \pm 1 \mathrm{~K}$ for $3 \mathrm{~h}$. Then, the specimens were washed thoroughly and weighed.

\section{Effect of Temperature on Corrosion Inhibition}

The effect of different temperatures $(313,323,333$, and $343 \pm 1 \mathrm{~K})$ on different concentrations $(100,200,300,400,500$, and $600 \mathrm{ppm})$ of $C$. tagal extract was tested for $3 \mathrm{~h}$. The same method as in concentration was followed. The weight of each specimen was noted before and after immersion to calculate the corrosion inhibition. 


\subsubsection{Atomic Adsorption Spectrometric (AAS)}

The concentration of $\mathrm{Fe}^{+}$ions in corrodent solutions without and with green inhibitors were examined by AAS to provide a clear picture about the formation of protective films on the test specimen. The mild steel coupons of $0.785 \mathrm{~cm}^{2}$ size were kept incubated in $1 \mathrm{M} \mathrm{HCl}$ without and with different concentrations (100, 200, 300, 400, 500, and $600 \mathrm{ppm}$ ) of C. tagal extract for $3 \mathrm{~h}$ at $303 \pm 1 \mathrm{~K}$ [31]. After incubation, the corrodent solutions of both uninhibited and inhibited samples were read for absorbance in an atomic absorption spectrometer (AAS, Model GB 908, Australia). The percentage inhibition efficiency was calculated using the following equation:

$$
\text { Inhibition efficiency }(\eta \%)=\mathrm{B}-\mathrm{A} / \mathrm{B} \times 100
$$

where B and A are the amount of dissolved iron in the absence (B) and the presence (A) of the inhibitor, respectively.

\subsubsection{UV-Visible Spectroscopy Analysis}

The UV-visible spectroscopic analysis was performed to understand the complex formation of inhibitor solution. In the experiment, samples were scratched out from before and after treating the surface of mild steels with the optimum concentration of $C$. tagal extract. UV-visible spectra were observed in the range of wavelengths from 200 to $800 \mathrm{~nm}$ using a UV 3000+ (India).

\subsubsection{Surface Analysis by SEM-EDX}

The mild steel specimens were immersed in $1 \mathrm{M} \mathrm{HCl}$ without and with $600 \mathrm{ppm}$ of plant extract and incubated for $3 \mathrm{~h}$ at $303 \pm 1 \mathrm{~K}$ [32]. After incubation, the surfaces of both the specimens were screened by scanning electron microscopy (SEM) (JEOL Model, Coimbatore, India) coupled with an energy-dispersive X-ray spectrometer (EDX) (JEOL Model JSM-6390).

\subsubsection{Atomic Force Microscopy (AFM)}

The surface topography of the mild steel in $1 \mathrm{M} \mathrm{HCl}$ in the presence and the absence of $600 \mathrm{ppm}$ inhibitor was assessed using an atomic force microscope (NTMDT, NTEGRA Prima, Russia). The specimens $\left(1 \times 1 \mathrm{~cm}^{2}\right)$ in size were incubated in $1 \mathrm{M} \mathrm{HCl}(100 \mathrm{~mL})$ and with C. tagal (600 ppm) inhibitor at $303 \pm 1 \mathrm{~K}$ for $3 \mathrm{~h}$, as described. After incubation, the mild steel specimens were washed with triple distilled water, dried thoroughly, and then the images were visualized to examine the morphological changes.

\section{Results and Discussion}

\subsection{TPC-TFC}

The presence of total phenols and flavonoids in plants is an indicator to use as a tool for solving several problems starting from the human body to industrial sectors. Polyphenols are the key ingredient for both antioxidant and pro-oxidant reactions [33,34]. For many years, the TPC and TFC of any plant have been approved as a benchmark for analyzing plant components for other economically beneficial roles. C. tagal plant extract had 101.52 and $35.71 \mathrm{mg} / \mathrm{g}$ of TPC and TFC (Figure 2), which further inspired checking the antioxidant and anticorrosive efficiency, as plants with significant amounts of TPC and TFC are excellent sources for inhibiting free radicals, pathogen, and corrosion [35-37]. 


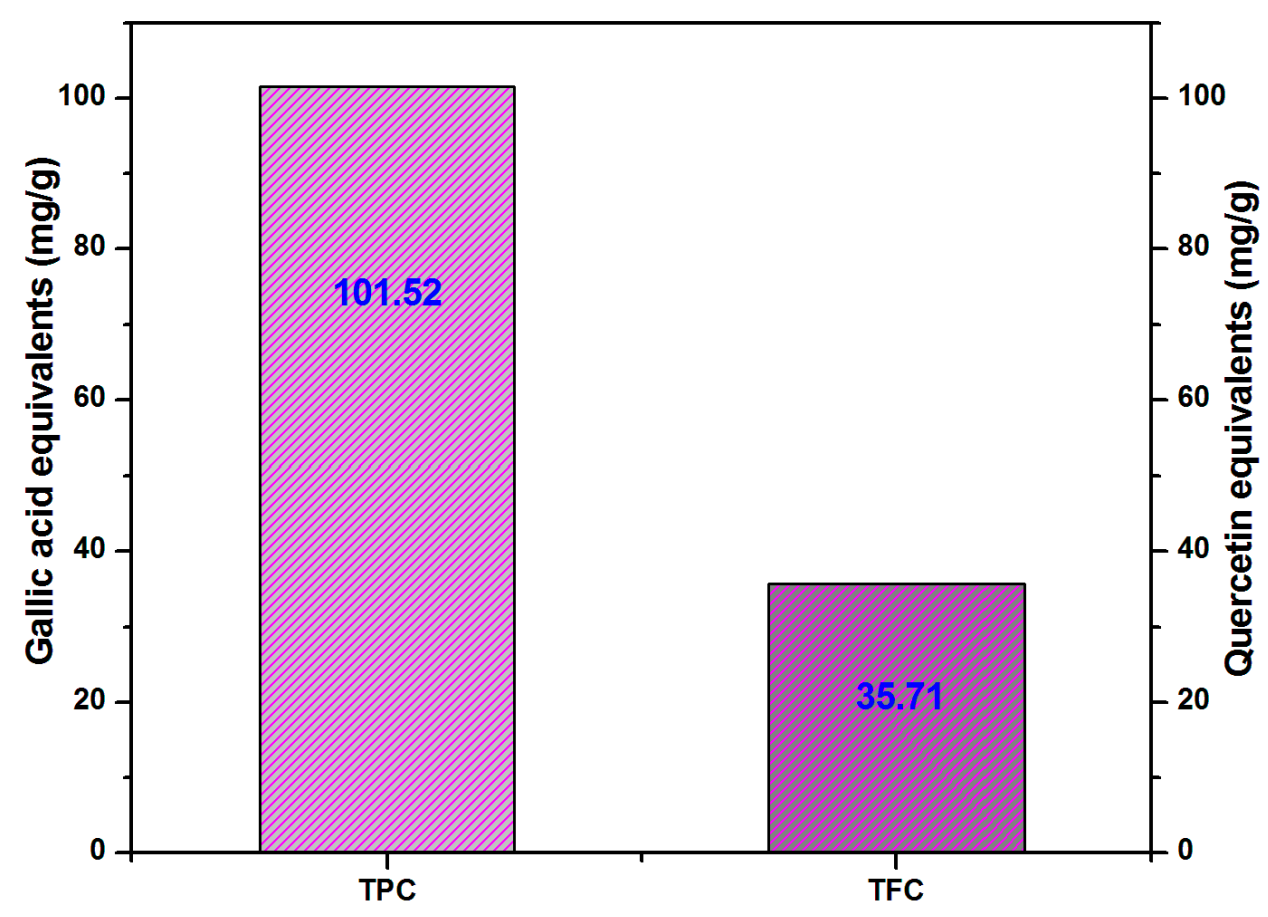

Figure 2. TPC and TFC of C. tagal plant extract.

The total phenol content and flavonoids, here, helps to gain a better understanding about various other crucial roles of $C$. tagal. In general, polyphenols from natural materials such as beverages, fruits, vegetables, and cereals are proven excellent sources for fighting against free radicals and diseases such as diabetes, neurodegenerative, and osteoporosis. These are compounds, either as intermediate or as precursor, are classified as phenols, flavonoids, and many more based on their structure and number of phenol rings [38]. In precise, phenols have a benzene ring attached to one or more hydroxyl groups, whereas flavonoids have two aromatic $\mathrm{C} 6-\mathrm{C} 3-\mathrm{C} 6$ ring structures assisting in specific and non-specific mechanisms with tremendous beneficial roles in human health [39].

\subsection{Antioxidant Studies}

The antioxidant studies of plant extracts provide a guide to identify the real role of active compounds in plants. The importance of antioxidant activity of plants has been a topic of interest for many years as it is either directly or indirectly connected to cures for many diseases such as neurodegenerative, endothelial dysfunction, inflammation, infection, and asthma $[34,38,39]$. The experiments on antioxidant activities of $C$. tagal were analyzed by DPPH, nitric oxide, hydrogen peroxide free radicals scavenging, total antioxidant capacity (Figure 3a-d), and reducing potential methods which are a few of the standard procedures. 

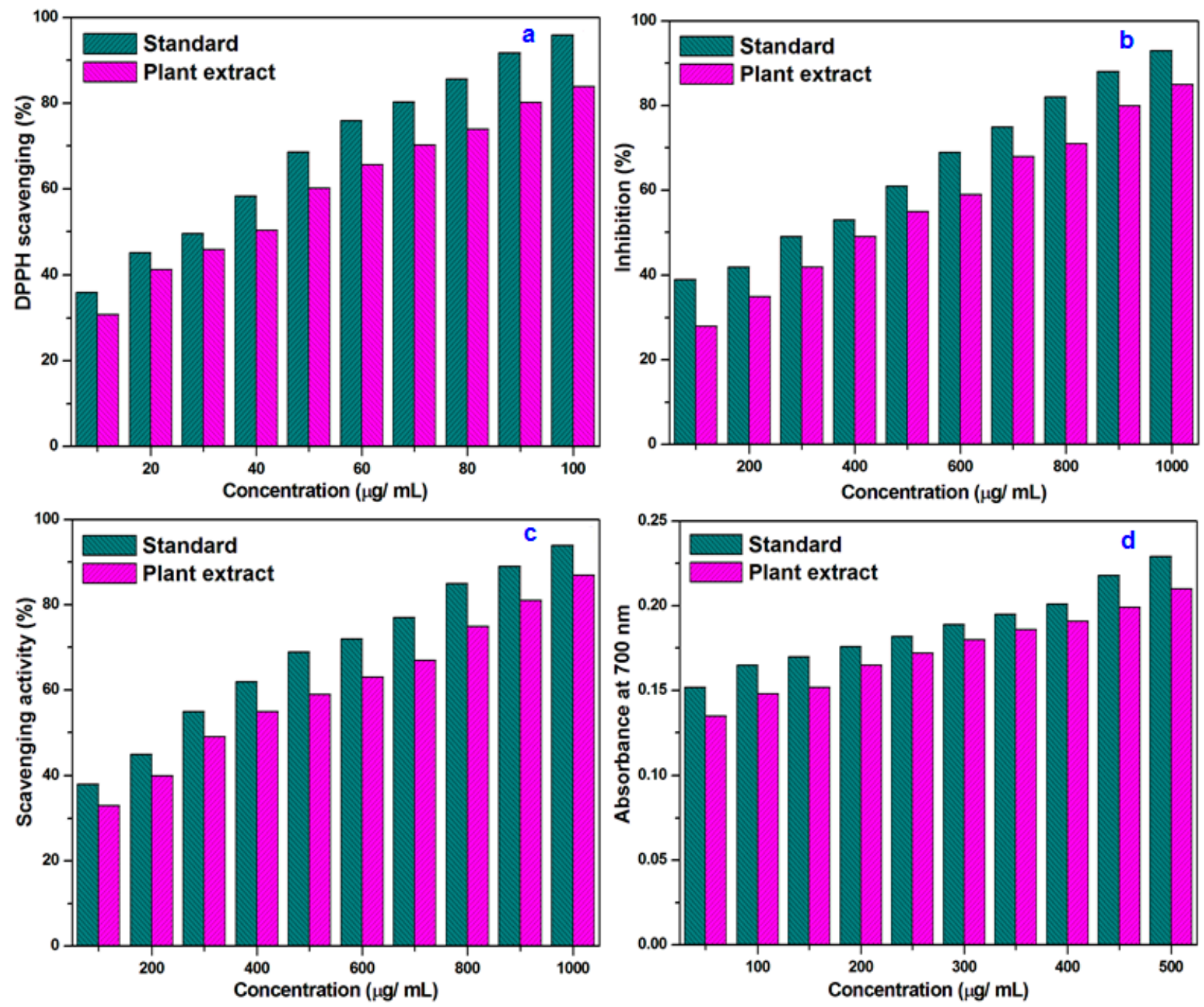

Figure 3. Antioxidant activities of C. tagal: (a) DPPH free-radical scavenging; (b) nitric oxide inhibition; (c) hydrogen peroxide free-radical scavenging; (d) reducing power.

\subsubsection{DPPH Free Radical Scavenging Assay}

DPPH free radical is a stable compound which, when it receives hydrogen atoms from plant extract, changes its color from purple to yellow. This change is measured by a decrease in absorbance indicating an increase in percentage of free radical scavenged in a concentration dependent manner [40]. The results in Figure 3a, show the antioxidant potential of $C$. tagal extract in a concentration dependent manner ranging from 30.87 to $83.88 \%$ for $10-100 \mu \mathrm{g} / \mathrm{mL}$, respectively. Various studies have also found that antioxidant activity is dependent on the structure of substrate molecules apart from concentration [41].

\subsubsection{Nitric Oxide Inhibition}

The nitric oxide inhibition (Figure $3 b$ ) of the plant extract corresponded to the DDPH assay with respect to concentration. The highest scavenging (85\%) was found at $1000 \mu \mathrm{g} / \mathrm{mL}$ and the lowest $(28 \%)$ was observed at $100 \mu \mathrm{g} / \mathrm{mL}$, as mentioned in a previous study [42]. Generally, nitric oxides have unpaired electrons that readily react with some proteins and free radicals such as superoxide forming peroxynitrite anion that are linked to inflammation and carcinomas. The role of phenols, flavonoids, and saponins was unveiled when monitoring the mechanism behind scavenging free radicals. The factor behind this was attributed to the redox potential of plant metabolites transfering them as hydrogen donors, singlet oxygen quenchers, and reducing elements. Thus, this creates a correlation 
between the phenols (concentration, types, and structure) and antioxidant potential of those compounds to encounter free radicals [41-43].

\subsubsection{Hydrogen Peroxide Free Radical Scavenging}

The reduction of hydrogen peroxide was as per the concentration of the extract, as shown in Figure 3c. The highest scavenging was observed at $1000 \mu \mathrm{g} / \mathrm{mL}$ with $87 \%$ and the lowest was observed at $100 \mu \mathrm{g} / \mathrm{mL}$ with $33 \%$. Overall, a gradual increase in radical scavenging was observed from least to highest concentration, similar to the DPPH and nitric oxide assays. The antioxidant (for instance phenols and flavonoids) present in the extract actively reduces the reactive oxygen species (hydrogen peroxide) into water by donating electrons in a dose dependent manner [27]. The present results also show the same pattern as several previous studies that reported on Helichrysum longifolium DC, Newbouldia laevis, and Zizyphus jujuba Miller [27,42,44].

\subsubsection{Reducing Potential of Plant Extract}

The reducing power assay that analyzed the reduction of $\mathrm{Fe}^{3+}$ to $\mathrm{Fe}^{2+}$ through electron transfer from antioxidants were found to be adequate. As shown in Figure $3 \mathrm{~d}$, the best reduction was found at $500 \mu \mathrm{g} / \mathrm{mL}$ in a concentration dependent manner when decreasing at a lower concentration, i.e., $50 \mu \mathrm{g} / \mathrm{mL}$, reciprocating other antioxidant assays of $C$. tagal and earlier studies of Helichrysum longifolium DC and Limnophila aromatica. Thus, identifying the reducing power corroborates with the antioxidant nature of active compounds from plants $[27,45,46]$.

\subsubsection{Phosphomolybdate Method}

The total antioxidant capacity performed by reading the reduction of Mo (IV) to Mo (V) was found to produce significant activity $(789.54 \mathrm{mg} / \mathrm{g})$ at given concentration of plant extract read at $659 \mathrm{~nm}$. Usually, mangroves are specialized in producing a high number of antioxidants related to its external stress factors such as salinity, toxicity, drought, temperature, and nutrient deficiency. They also have a strong enzymatic system for defense, namely catalase, superoxide dismutase, and glutathione reductase to protect them from these stressful environments. Plants such as Lumnitzera racemosa, Rhizophora mucronatz scvatxe, Suaeda maritima, and Sonneratia caseolaris have been identified to produce phenols, terpenoids, saponins, steroids, and tannins as antioxidants [5]. These antioxidant capabilities have been studied by methods including DPPH, nitric oxide, and hydrogen peroxide scavenging activity, and phosphomolybdenum assays in Acanthus ilicifolius L., Rhizophora mucronata Lam., and Rhizophora apiculata Blume in leaf, root, stem, and bark [9,46].

\subsection{Corrosion Inhibition}

Corrosion inhibition by C. tagal extract was measured by various analyses focusing on weight loss at different concentrations and temperatures, difference in dissolved ions, functional groups, surfaces of specimens, and percentage composition. The best results were obtained with $3 \mathrm{~h}$ of immersion, therefore, we chose $3 \mathrm{~h}$ as the best immersion time.

\subsubsection{Weight Loss Measurement \\ Effect of Concentration}

The inhibition competency of different concentrations (100, 200, 300, 400, 500, and $600 \mathrm{ppm}$ ) of $C$. tagal extract was tested against mild steel in $1 \mathrm{M} \mathrm{HCl}$ at $303 \pm 1 \mathrm{~K}$. Maximum $\eta \%$ (95) was established by $600 \mathrm{ppm}$, from there the inhibition tended to decrease (49\%) until $100 \mathrm{ppm}$, as presented in Table 1. 
Table 1. \% IE for various concentrations (Conc.) of the C. tagal extracts for corrosion of mild steel in 1 $\mathrm{M} \mathrm{HCl}$ obtained by weight loss measurements at room temperature (303 $\pm 1 \mathrm{~K})$.

\begin{tabular}{ccccc}
\hline Conc. $(\mathbf{p p m})$ & $\mathbf{W}\left(\mathbf{m g} \cdot \mathbf{c m}^{-2}\right)$ & $\boldsymbol{\theta}$ & $\boldsymbol{\eta} \%$ & $\boldsymbol{\sigma}^{\mathbf{a}}$ \\
\hline Blank & 0.0989 & - & - & - \\
100 & 0.0501 & 0.49 & 49 & 0.03 \\
200 & 0.0432 & 0.56 & 56 & 0.02 \\
300 & 0.0388 & 0.61 & 61 & 0.01 \\
400 & 0.0298 & 0.70 & 70 & 0.02 \\
500 & 0.0102 & 0.90 & 90 & 0.03 \\
600 & 0.0055 & 0.95 & 95 & 0.01 \\
\hline
\end{tabular}

a $\sigma$ is the standard deviation.

Several previous reports have reported the influence of inhibitor concentration in decreasing corrosion rate. Studies had emphasized the correlation between the surface coverage $(\theta)$, concentration, and inhibition efficiency $(\eta \%)$ which perfectly suits the action of $C$. tagal extract, as in Table 1 [47-49]. Here, the surface coverage $(\theta)$ values increased with an increase in concentration, as the higher concentration increased the strength of the protective layer, thereby, lifting the inhibition efficiency of the extract at $303 \pm 1 \mathrm{~K}[50,51]$.

\section{Effect of Temperature}

C. tagal extract was tested against $1 \mathrm{M} \mathrm{HCl}$ with different temperatures $(313,323$, 333 , and $343 \pm 1 \mathrm{~K}$ ) and concentrations (100, 200, 300, 400, 500, and $600 \mathrm{ppm})$ for $3 \mathrm{~h}$. Table 2 reveals the effect of change in concentration and temperature affecting the $\eta \%$ at a large scale.

Table 2. The $\eta \%$ values for various concentrations (Conc.) and temperatures of C. tagal extract for mild steel corrosion in $1 \mathrm{M} \mathrm{HCl}$ by weight loss measurements.

\begin{tabular}{|c|c|c|c|c|c|}
\hline $\mathrm{T}( \pm \mathbf{K})$ & Conc. (ppm) & $\mathrm{W}\left(\mathrm{mg} \cdot \mathrm{cm}^{-2}\right)$ & $\theta$ & $\eta \%$ & $\sigma^{a}$ \\
\hline \multirow{7}{*}{313} & Blank & 0.1251 & - & - & - \\
\hline & 100 & 0.0702 & 0.44 & 44 & 0.02 \\
\hline & 200 & 0.0633 & 0.49 & 49 & 0.04 \\
\hline & 300 & 0.0504 & 0.60 & 60 & 0.03 \\
\hline & 400 & 0.0413 & 0.67 & 67 & 0.03 \\
\hline & 500 & 0.0331 & 0.74 & 74 & 0.02 \\
\hline & 600 & 0.0209 & 0.83 & 83 & 0.03 \\
\hline \multirow{9}{*}{323} & Blank & 0.1410 & - & - & - \\
\hline & 100 & 0.0857 & 0.39 & 39 & 0.02 \\
\hline & 200 & 0.0758 & 0.46 & 46 & 0.01 \\
\hline & 300 & 0.0701 & 0.50 & 50 & 0.03 \\
\hline & 400 & 0.0598 & 0.58 & 58 & 0.01 \\
\hline & 500 & 0.0503 & 0.64 & 64 & 0.02 \\
\hline & 600 & 0.0328 & 0.77 & 77 & 0.02 \\
\hline & Blank & 0.1787 & - & - & - \\
\hline & 100 & 0.1221 & 0.32 & 32 & 0.02 \\
\hline \multirow{5}{*}{333} & 200 & 0.1151 & 0.36 & 36 & 0.03 \\
\hline & 300 & 0.1020 & 0.43 & 43 & 0.01 \\
\hline & 400 & 0.0852 & 0.52 & 52 & 0.01 \\
\hline & 500 & 0.0757 & 0.58 & 58 & 0.02 \\
\hline & 600 & 0.0629 & 0.65 & 65 & 0.02 \\
\hline \multirow{7}{*}{343} & Blank & 0.2002 & - & - & - \\
\hline & 100 & 0.1485 & 0.26 & 26 & 0.02 \\
\hline & 200 & 0.1302 & 0.35 & 35 & 0.03 \\
\hline & 300 & 0.1221 & 0.39 & 39 & 0.01 \\
\hline & 400 & 0.1112 & 0.44 & 44 & 0.02 \\
\hline & 500 & 0.1021 & 0.49 & 49 & 0.03 \\
\hline & 600 & 0.0921 & 0.54 & 54 & 0.02 \\
\hline
\end{tabular}

${ }^{a} \sigma$ is the standard deviation. 
This test shows the inability of a high concentration (600 ppm) in inhibiting corrosion $(54 \%)$ at $343 \pm 1 \mathrm{~K}$. Although concentration helped to increase the inhibition efficiency and to decrease corrosion rate, a gradual fall in surface coverage $(\theta)$ and $\eta \%$ were observed at $313,323,333$, and $343 \pm 1 \mathrm{~K}$. A change in $\eta \%$ according to the rise in temperature has been observed in plants such as Mentha pulegium, Zenthoxylum alatum, Jojoba oil, Aster koraiensis, and Cryptostegia grandiflora due to decreased adsorption and increased desorption of inhibitor along with an increase in hydrogen evolution [23,25].

\subsubsection{Atomic Adsorption Spectrometric (AAS)}

The concentration of $\mathrm{Fe}+$ ions in the corrodent solution of both types are presented in Table 3.

Table 3. AAS study for different concentrations of $C$. tagal extract in $1 \mathrm{M} \mathrm{HCl}(303 \pm 1 \mathrm{~K})$.

\begin{tabular}{cccc}
\hline Conc. $(\mathbf{p p m})$ & Amount of Mild Steel Corrodant $\mathbf{( m g / I )}$ & $\boldsymbol{\eta ( \% )}$ & $\boldsymbol{\sigma}^{\mathbf{a}}$ \\
\hline Blank & 45.214 & - & - \\
100 & 32.546 & 28 & 0.01 \\
200 & 28.541 & 37 & 0.03 \\
300 & 25.299 & 44 & 0.02 \\
400 & 20.548 & 55 & 0.04 \\
500 & 12.571 & 72 & 0.02 \\
600 & 08.254 & 82 & 0.02 \\
\hline
\end{tabular}

a $\sigma$ is the standard deviation.

Maximum inhibition (81.74\%) was found at $600 \mathrm{ppm}$ which was reduced to $28 \%$ at $100 \mathrm{ppm}$. These results showcase the presence of a protective layer on mild steel immersed in C. tagal extract with varying concentrations of $\mathrm{Fe}+$ ions in the corrodent solution based on concentration. Variations in the amounts of ions in both the solutions (without and with plant extract) were due to the presence of a protective film which barred the corrosion to about $82 \%$ ( $8.25 \mathrm{mg} / \mathrm{I}$ of mild steel corrodent) [52]. The inhibition was concentration dependent, since a decrease in $\eta \%$ was observed at lower concentrations ranging from 28 to $72 \%$ for $200-500 \mathrm{ppm}$. The change was due to the acid attack which had occurred by larger exposure of the mild steel surface. Usually organic compounds with sulfur, nitrogen, and oxygen atoms are linked to aromatic rings forming a conjugate system in order to provide electronegative space for interacting with the metal surface to shield them from corrosive environment. This type of shielding has been observed in biomass (Pseudomonas chlororaphis) and plants (Senna cana, Zanthoxylum syncarpum Tull., Dimorphandra gardneriana Tul., and Mangifera indica L.) via their aminophenol derivatives and heterocyclic compounds (phenols, alkaloids, anthocyanidins, and saponins) being adsorbed onto the metal surface decreasing the chance for oxidation and preventing corrosion [53,54].

\subsubsection{UV-Visible Spectroscopy Analysis}

The anticorrosion effect of $1 \mathrm{M} \mathrm{HCl}$ with the presence and the absence of $\mathrm{C}$. tagal (600 ppm) inhibitor treatment on mild steel was determined and shown in Figure 4 . The change in absorbance maximum clearly shows the formation of an inhibitor metal complex. The absorption spectra of the pure $C$. tagal extract before immersion reveal maximum absorption at $320 \mathrm{~nm}$ (Figure $4 \mathrm{a}$ ), corresponding to $\pi-\pi^{*}$ and $n-\pi^{*}$ transition for carbonyl $\mathrm{C}=\mathrm{O}$ and $\mathrm{N}-\mathrm{H}$ groups, respectively. The variation in the absorption maximum of treated C. tagal (600 ppm) inhibitor solution (Figure $4 \mathrm{~b}$ ) displayed shifted absorption regions to 285 and $360 \mathrm{~nm}$. These estimations reveal the significant change in the position of the absorption maximum after immersion of mild steel. Hence, the change in the absorption maximum position showed the formation of the complex between the $1 \mathrm{M} \mathrm{HCl}$ and the (600 ppm) C. tagal inhibitor solution. 

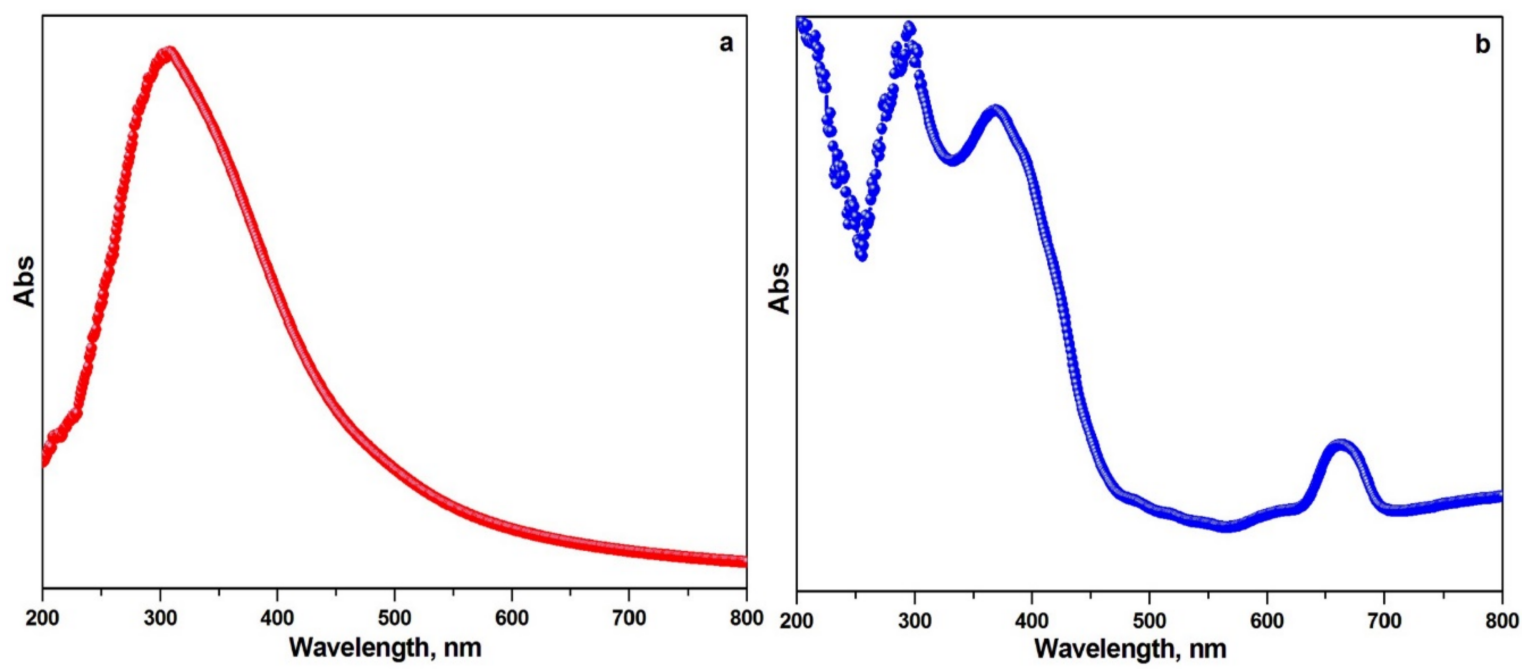

Figure 4. UV-visible spectrum of: (a) Pure C. tagal extract; (b) inhibited C. tagal.

\subsubsection{Surface Analysis by SEM-EDX}

Figure 5a,b, representing the SEM images of mild steel without and with 600 ppm of C. tagal extract in $1 \mathrm{M} \mathrm{HCl}$, is yet another observation made that supports enhancing the role of $C$. tagal extract on corrosion inhibition.
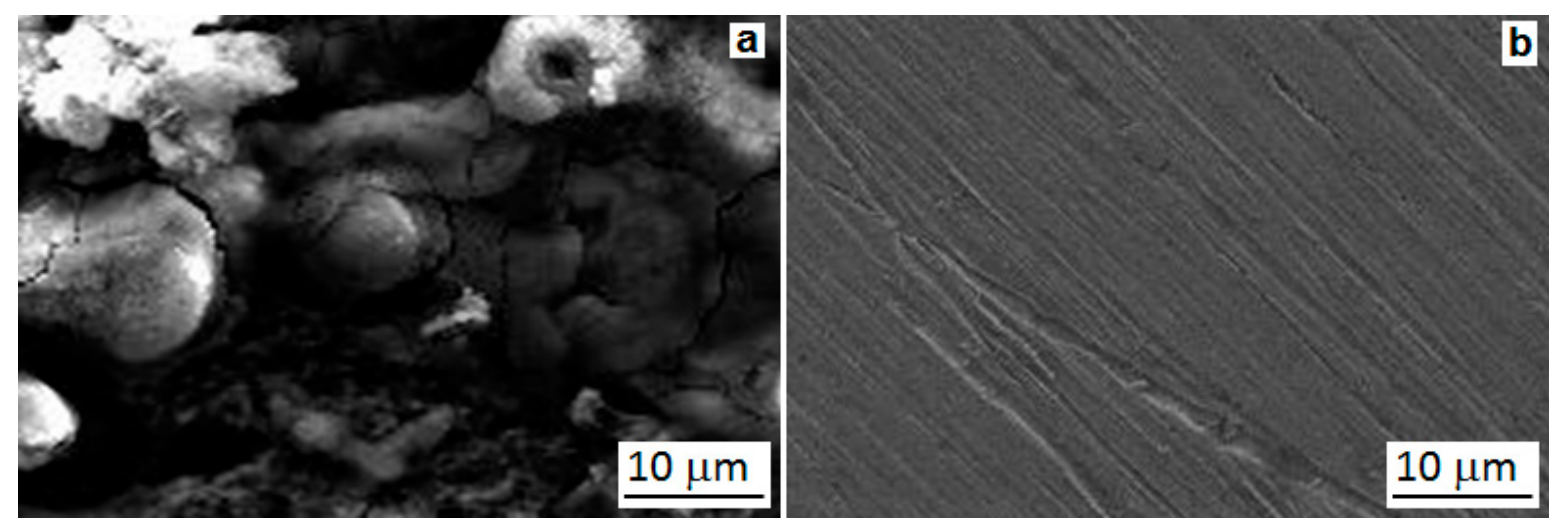

Figure 5. SEM photographs of mild steel dipped in: (a) $1 \mathrm{M} \mathrm{HCl}$; (b) $1 \mathrm{M} \mathrm{HCl}$ with 600 ppm of inhibitor.

The roughness, large pores, cracks, and pits on the surface of mild steel, shown in Figure 5a, indicate an aggressive acid attack causing corrosion, whereas the smooth and even surface (Figure $5 b$ ) are due to the protective film formed by plant extract. In addition to these results, numerous studies on mild steel have demonstrated the possibility of plant metabolites for protecting metal surface from corrosion [55-57]. The differences in the elemental composition in both uninhibited and inhibited samples were clearly identified in EDX. Figure $6 \mathrm{a}, \mathrm{b}$ shows the variation in the percentage composition of elements in blank and inhibited that provides proof of the action of $C$. tagal active compounds on mild steel surface [58].

Secondary metabolites such as phenols, tannins, carbohydrates, and proteins are known for their shielding effects on metals and alloys, which is the bases for the reduction in corrosion rate by preventing oxidation [58]. It is clear that the differences in Table 4 and Figure $6 \mathrm{a}$, with $71.54 \% \mathrm{Fe}, 22.1 \% \mathrm{O}, 4.34 \% \mathrm{C}$, and $1.51 \% \mathrm{Mn}$, and Figure $6 \mathrm{~b}$, with $84.21 \% \mathrm{Fe}, 9.01 \% \mathrm{O}, 6.37 \% \mathrm{C}$, and $0.07 \% \mathrm{Mn}$, represents the acid attack depleting iron atoms by oxidizing the mild steel. The latter with a lower percentage of oxygen and higher percentage of iron atoms shows a decrease in acid attack due to the protective film of plant extract $[59,60]$. This assures that the decreased corrosion rate might be due to the active ingredient in plant extract. 

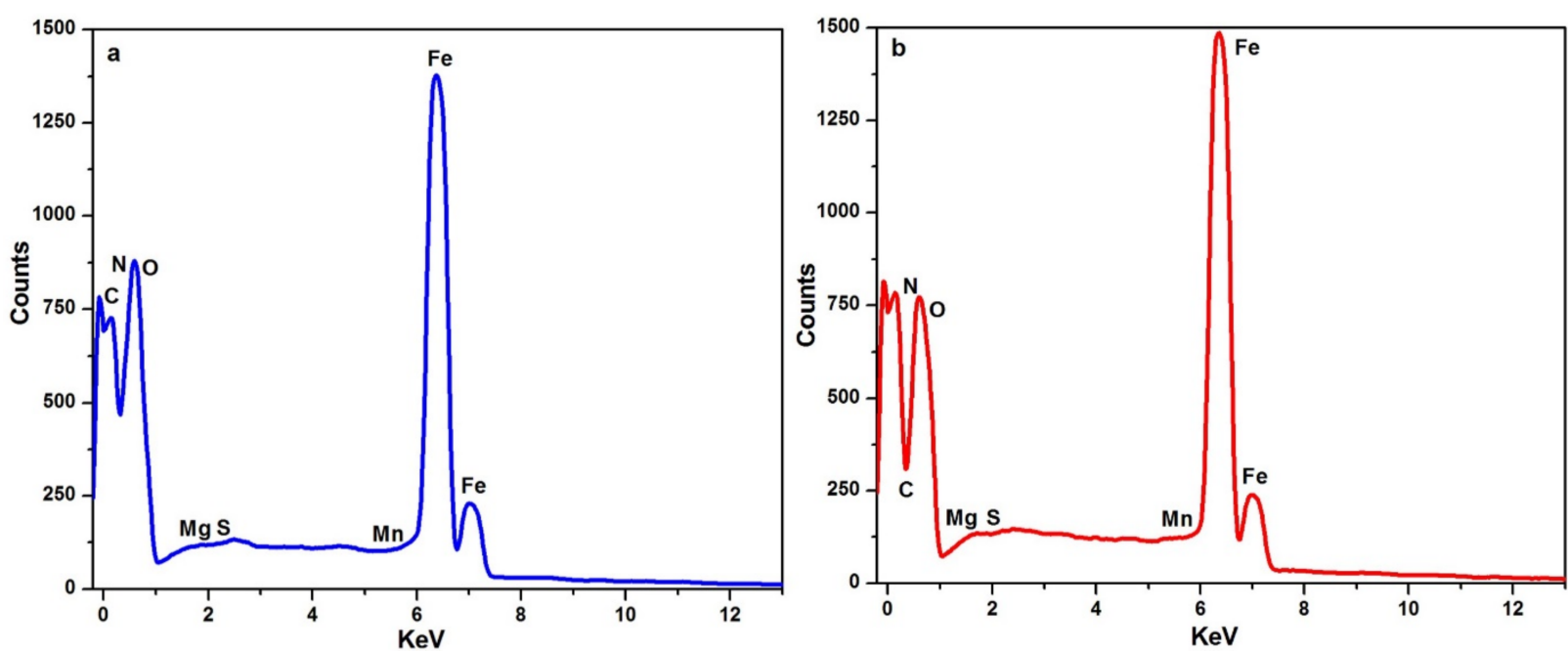

Figure 6. EDX spectra of mild steel dipped in: (a) $1 \mathrm{M} \mathrm{HCl}$; (b) $1 \mathrm{M} \mathrm{HCl}$ with 600 ppm of inhibitor.

Table 4. Percentage compositions of elements present on the mild steel surface.

\begin{tabular}{ccc}
\hline \multirow{2}{*}{ Elements } & \multicolumn{2}{c}{ Composition (Atomic\%) } \\
\cline { 2 - 3 } & Blank & Inhibited \\
\hline $\mathrm{C}$ & 4.34 & 6.37 \\
$\mathrm{Fe}$ & 71.54 & 84.21 \\
$\mathrm{O}$ & 22.10 & 9.01 \\
$\mathrm{~S}$ & 0.12 & 0.11 \\
$\mathrm{~N}$ & 0.18 & 0.12 \\
$\mathrm{Mn}$ & 1.51 & 0.07 \\
$\mathrm{Mg}$ & 0.21 & 0.11 \\
\hline
\end{tabular}

\subsubsection{AFM}

AFM is a potent tool for determining the surface topography of the polished mild steel exposed to $(1 \mathrm{M}) \mathrm{HCl}$ along with and without green inhibitor. As shown in Figure 7, the two-dimensional (2D) surface morphology of mild steel treated with $1 \mathrm{M} \mathrm{HCl} \mathrm{reveals} \mathrm{a}$ severe crack in the surface (Figure 7a) and $1 \mathrm{M} \mathrm{HCl}$ with $600 \mathrm{ppm}$ inhibitor significantly diminished the surface crack (Figure $7 \mathrm{~b}$ ) [61-63]. The average roughness $(251 \mathrm{~nm})$ of the mild steel before the exposure to acidic solution were noticed and, in the presence of the optimal concentration of $C$. tagal plant extract, the reduced average roughness was determined $(65 \mathrm{~nm})$, which confirmed the anticorrosion efficiency of the adsorbed inhibitor molecules produced by the protective film [64-66].

\subsubsection{Corrosion Mechanism}

The most relevant mechanism behind the inhibition of corrosion by plant extract against mild steel in $1 \mathrm{M} \mathrm{HCl}$ is represented in Figure 8.

They are a few possible ways that components in any plant extract interact and interrupt corrosion. The active metabolites adsorbed on the surface of metal are affected by the structure of inhibitors, the metal's surface and nature, and the type of corrosive medium used [67]. Organic compounds such as phenols, flavonoids, amino acids, dye, etc. are known green inhibitors as they are non-toxic, go easy, biodegradable, and cost effective. Experiments on metals in aggressive solutes such as $\mathrm{HCl}$ and $\mathrm{H}_{2} \mathrm{SO}_{4}$ have successfully found several new plant-based materials as corrosion inhibitors, as these compounds pose heteroatoms such as $\mathrm{O}, \mathrm{S}, \mathrm{N}$, and $\mathrm{P}$ which are oxidized on the metal surface or adsorbed in the metal forming protective layer [60]. Apparently, the inhibition mechanism is strongly influenced by the choice of electrolyte, nature of metal, structure and concentration of inhibitors, temperature, and $\mathrm{pH}$. In the case of electrolyte, variations in inhibitor behavior (lawsonia extract) were observed against corrosion of nickel and C-steel 
in neutral, acid, and alkaline mediums. On the one hand, nitrogen and sulfur containing compounds, alkaloids, and aldehydes influence acid media; on the other hand, chromate, nitrite, and phosphate act on neutral media [12,33]. The green inhibitors are heterocyclic with functional polar groups (-OH, $-\mathrm{CH}_{3},-\mathrm{OCH}_{3},-\mathrm{NO}_{2}$, and $\left.-\mathrm{COOH}\right)$. The functional polar groups along conjugated $\pi$-electrons with double/triple bonds aid in adsorption, thereby, blocking cathodic and anodic reaction results in corrosion inhibition [56,68-71].

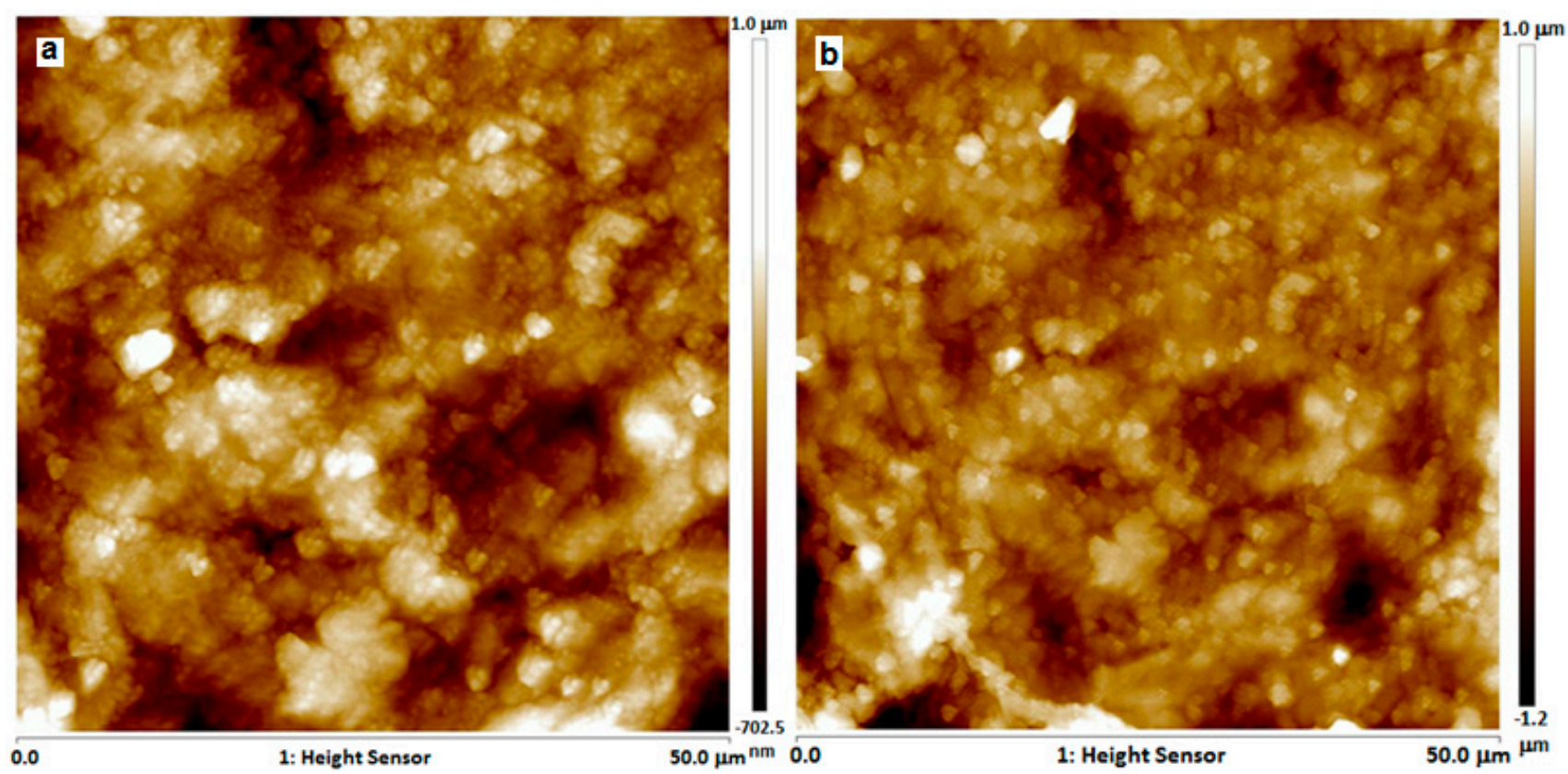

Figure 7. 2D images of mild steel: (a) $1 \mathrm{M} \mathrm{HCl}$; (b) $1 \mathrm{M} \mathrm{HCl}$ with 600 ppm of inhibitor.

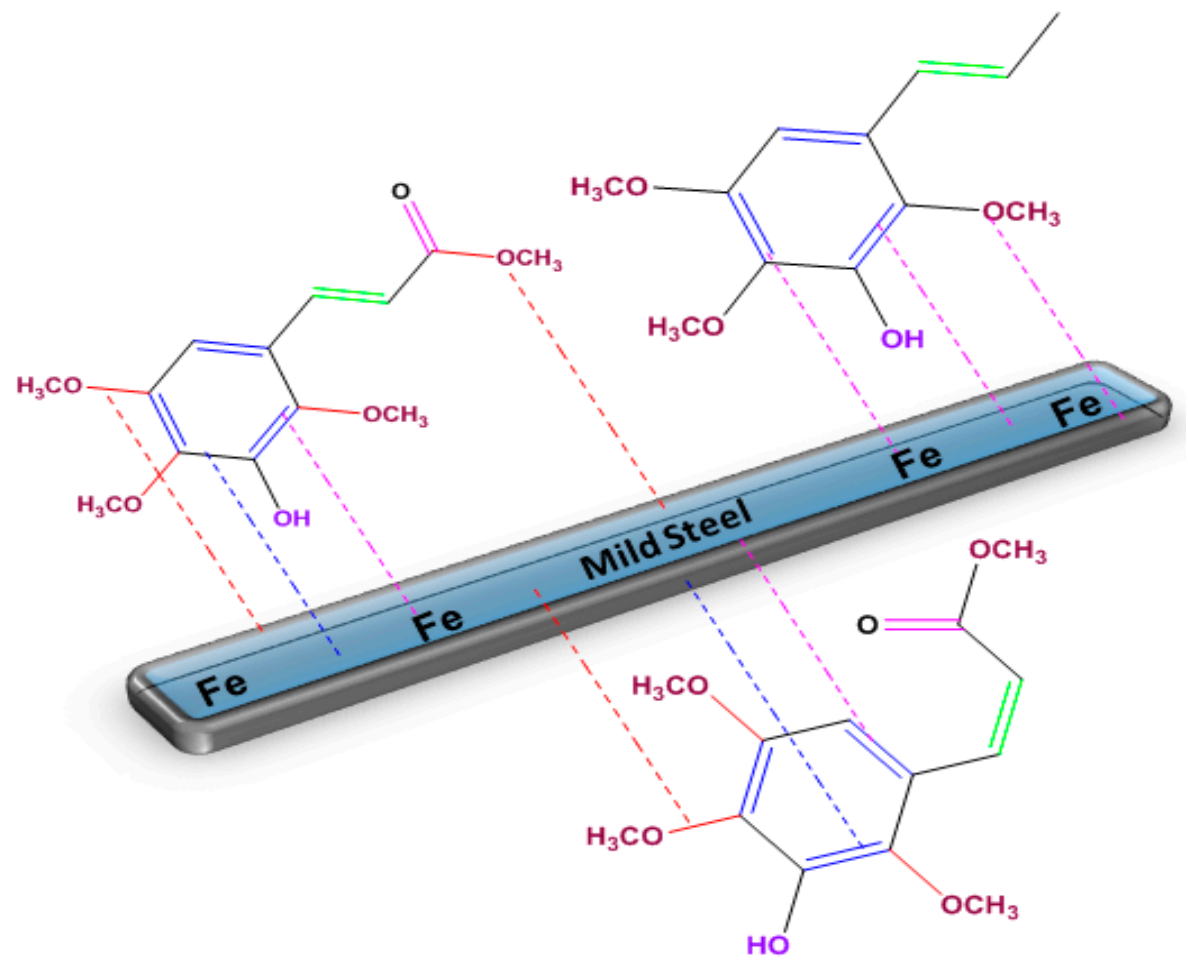

Figure 8. An illustration of possible corrosion mechanism of C. tagal extract. 


\subsubsection{Corrosion Comparison}

It is evident that $C$. tagal extract is competent with other known green inhibitors, as it exhibits the strongest inhibition against mild steel corrosion in $1 \mathrm{M} \mathrm{HCl}$. As in Table 5, plant extracts such as Aster koraiensis (90.53\%) [23], Cryptostegia grandiflora (87.54\%) [25], sweet melon peel (91.59\%) [30], Desmodium triflorum (92.99\%), Polycarpaea corymbose (91.78\%) [32], Citrullus lanatus (91\%) [57], Lawsonia inermis (92.06\%) [62], Lepidagathis keralensis (92.73\%) [63], Mangifera indica (92\%) [64], Mentha pulegium (80\%) [65], and Petroselium Sativum (92.39\%) [66] were overcome by the acceptable results of $C$. tagal extract.

Table 5. Comparison of C. tagal (present) green inhibitor over other green inhibitors.

\begin{tabular}{ccc}
\hline S. No & Green Inhibitor & $\eta \mathbf{( \% )}$ \\
\hline 1. & Aster koraiensis & $90.53[23]$ \\
2. & Ceriops tagal & 95 \\
3. & Cryptostegia grandiflora & $87.54[25]$ \\
4. & Sweet melon peel & $91.59[30]$ \\
5. & Desmodium triflorum & $92.99[32]$ \\
6. & Polycarpaea corymbosa & $91.78[32]$ \\
7. & Citrullus lanatus & $91.00[57]$ \\
8. & Lepidagathis keralensis & $92.06[72]$ \\
9. & Mangifera indica & $92.73[73]$ \\
10. & Mangifera indica & $92.00[74]$ \\
11. & Mentha pulegium & $80.00[75]$ \\
12. & Petroselium Sativum & $92.39[76]$ \\
\hline
\end{tabular}

\# Present work.

\section{Conclusions}

- This study mainly focuses on emphasizing the eminent role of the incredible mangrove plant $C$. tagal in preventing oxidation and corrosion.

- The amount of TPC and TFC highlights the need to focus on other active ingredient in C. tagal to learn more about the plant in the future.

- The scavenging activity on DPPH, nitric oxide, and hydrogen peroxide portraits the performance of $C$. tagal as a successful antioxidant.

- The inhibition efficiency of the plants is more evident in weight loss, ASS, UV-visible, SEM-EDX, and AFM for corrosion inhibition.

- Although there is no direct correlation between the antioxidant and anticorrosive activities, similar studies on several other plants and their components have highlighted the role of secondary metabolites in both cases. Thus, the C. tagal plant can be taken for further research on metal inhibition and other pharmaceutical applications.

Author Contributions: Conceptualization, methodology, data curation, writing-original draft preparation, M.S.; conceptualization, resources, visualization, writing — original draft preparation, K.K.; conceptualization, software, investigation, data curation, writing—original draft preparation, writing - review and editing, supervision, project administration, M.P. All authors have read and agreed to the published version of the manuscript.

Funding: This research received no external funding.

Institutional Review Board Statement: Not applicable.

Informed Consent Statement: Not applicable.

Data Availability Statement: Not applicable.

Acknowledgments: This paper was supported by the KU Research Professor Program of Konkuk University.

Conflicts of Interest: The authors declare no conflict of interest. 


\section{References}

1. Hossain, M.; Nuruddin, A. Soil and Mangrove: A Review. J. Environ. Sci. Technol. 2016, 9, 198-207. [CrossRef]

2. Basha, S.K.C. An overview on global mangroves distribution. Indian J. Geo-Mar. Sci. 2018, 47, 766-772.

3. Ricklefs, R.E.; Latham, R.E. Global Patterns of Diversity in Mangrove Floras. Species Diversity in Ecological Communities: Historical and Geographical Perspectives; University of Chicago Press: Chicago, IL, USA, 1993; Chapter 20; pp. 215-229.

4. Khafagi, I.; Gab-Alla, A.; Salama, W.; Fouda, M. Biological activities and phytochemical constituents of the gray mangrove Avicennia marina (Forssk.) Vierh. Egypt. J. Biol. 2003, 5, 62-69.

5. Eswaraiah, G.; Peele, K.A.; Krupanidhi, S.; Kumar, R.B.; Venkateswarulu, T. Studies on phytochemical, antioxidant, antimicrobial analysis and separation of bioactive leads of leaf extract from the selected mangroves. J. King Saud Univ.-Sci. 2019, 32, 842-847. [CrossRef]

6. Cruz, S.M.; Marroquín, N.; Alvarez, L.E.; Chang, D.E.; Cáceres, A. Evaluation of mangrove (Rhizophora mangle L.) products as coloring, antimicrobial and antioxidant agents. Int. J. Phytocosmet. Nat. Ingred. 2015, 2, 12. [CrossRef]

7. Prabhu, V.V.; Guruvayoorappan, C. Phytochemical screening of methanolic extract of mangrove Avicennia marina (Forssk.) Vierh. Der Pharm. Sin. 2012, 3, 64-70.

8. Glasenapp, Y.; Korth, I.; Nguyen, X.V.; Papenbrock, J. Sustainable use of mangroves as sources of valuable medicinal compounds: Species identification, propagation and secondary metabolite composition. S. Afr. J. Bot. 2019, 121, 317-328. [CrossRef]

9. Bibi, S.N.; Fawzi, M.M.; Gokhan, Z.; Rajesh, J.; Nadeem, N.; Kannan, R.; Albuquerque, R.D.D.G.; Pandian, S.K. Ethnopharmacology, phytochemistry, and global distribution of mangroves-A comprehensive review. Mar. Drugs 2019, 17, 231. [CrossRef] [PubMed]

10. Rahim, A.A.; Rocca, E.; Steinmetz, J.; Kassim, M.J.; Ibrahim, M.S.; Osman, H. Antioxidant activities of mangrove Rhizophora apiculata bark extracts. Food Chem. 2008, 107, 200-207. [CrossRef]

11. Thatoi, H.; Behera, B.C.; Mishra, R.R.; Dutta, S.K. Biodiversity and biotechnological potential of microorganisms from mangrove ecosystems: A review. Ann. Microbiol. 2012, 63, 1-19. [CrossRef]

12. Kesavan, D.; Gopiraman, M.; Sulochana, N. Green inhibitors for corrosion of metals: A review. Chem. Sci. Rev. Lett. 2012, 1, 1-8.

13. Chigondo, M.; Chigondo, F. Recent Natural Corrosion Inhibitors for Mild Steel: An Overview. J. Chem. 2016, $2016,6208937$. [CrossRef]

14. Khan, G.; Md, K.; Newaz, S.; Basirun, W.J.; Ali, H.B.M.; Faraj, F.L.; Khan, G.M. Application of natural product extracts as green corrosion inhibitors for metals and alloys in acid pickling processes-A review. Int. J. Electrochem. Sci. 2015, 10, 6120-6134.

15. Fateh, A.; Aliofkhazraei, M.; Rezvanian, A. Review of corrosive environments for copper and its corrosion inhibitors. Arab. J. Chem. 2020, 13, 481-544. [CrossRef]

16. Xiao, X.; Hong, Y.; Xia, W.; Feng, S.; Zhou, X.; Fu, X.; Zang, J.; Xiao, Y.; Niu, X.; Li, C.; et al. Transcriptome Analysis of Ceriops tagal in Saline Environments Using RNA-Sequencing. PLoS ONE 2016, 11, e0167551. [CrossRef]

17. Kumar, V.A.; Ammani, K.; Siddhardha, B.; Sreedhar, U.; Kumar, G.A. Differential biological activities of the solvent extracts of Ceriops decandra (Griff.) and their phytochemical investigations. J. Pharm. Res. 2013, 7, 654-660. [CrossRef]

18. Ni, S.-J.; Li, J.; Li, M.-Y. Two New Dolabrane Diterpenes from the Chinese Mangrove Ceriops tagal. Chem. Biodivers. 2018, 15, e1700563. [CrossRef] [PubMed]

19. Yang, Y.; Zhang, Y.; Liu, D.; Li-Weber, M.; Shao, B.; Lin, W. Dolabrane-type diterpenes from the mangrove plant Ceriops tagal with antitumor activities. Fitoterapia 2015, 103, 277-282. [CrossRef] [PubMed]

20. Ni, S.-J.; Li, J.; Li, M.-Y. Two new phenylpropanoids from the Chinese mangrove Ceriops tagal. Nat. Prod. Res. 2017, 32, 1676-1681. [CrossRef]

21. Wang, P.; Cui, Y.; Cai, C.; Chen, H.; Dai, Y.; Chen, P.; Kong, F.; Yuan, J.; Song, X.; Mei, W.; et al. Two New Succinimide Derivatives Cladosporitins A and B from the Mangrove-derived Fungus Cladosporium sp. HNWSW-1. Mar. Drugs 2018, 17, 4. [CrossRef]

22. Wu, J.-T.; Zheng, C.-J.; Zhang, B.; Zhou, X.-M.; Zhou, Q.; Chen, G.-Y.; Zeng, Z.-E.; Xie, J.-L.; Han, C.-R.; Lyu, J.-X. Two new secondary metabolites from a mangrove-derived fungus Cladosporium sp. JJM22. Nat. Prod. Res. 2018, 33, 34-40. [CrossRef]

23. Prabakaran, M.; Kim, S.-H.; Mugila, N.; Hemapriya, V.; Parameswari, K.; Chitra, S.; Chung, I.-M. Aster koraiensis as nontoxic corrosion inhibitor for mild steel in sulfuric acid. J. Ind. Eng. Chem. 2017, 52, 235-242. [CrossRef]

24. Helen, L.Y.S.; Rahim, A.A.; Saad, B.; Saleh, M.I.; Raj, P.B. Aquilaria crassna leaves extracts-a green corrosion inhibitor for mild steel in $1 \mathrm{M} \mathrm{HCl}$ medium. Int. J. Electrochem. Sci. 2014, 9, 830-846.

25. Prabakaran, M.; Kim, S.-H.; Hemapriya, V.; Chung, I.-M. Evaluation of polyphenol composition and anti-corrosion properties of Cryptostegia grandiflora plant extract on mild steel in acidic medium. J. Ind. Eng. Chem. 2016, 37, 47-56. [CrossRef]

26. Alam, N.; Bristi, N.J. Rafiquzzaman Review on in vivo and in vitro methods evaluation of antioxidant activity. Saudi Pharm. J. 2012, 21, 143-152. [CrossRef]

27. Aiyegoro, O.A.; Okoh, A.I. Preliminary phytochemical screening and In vitro antioxidant activities of the aqueous extract of Helichrysum longifolium DC. BMC Complement. Altern. Med. 2010, 10, 21. [CrossRef] [PubMed]

28. Malathy, R.; Prabakaran, M.; Kalaiselvi, K.; Chung, I.M.; Kim, S.H. Comparative polyphenol composition, antioxidant and anticorrosion properties in various parts of panax ginseng extracted in different solvents. Appl. Sci. 2021, 11, 93. [CrossRef]

29. Hemapriya, V.; Chung, I.-M.; Kim, S.-H.; Prabakaran, M. Inhibitory effect of biowaste on copper corrosion in $1 \mathrm{M} \mathrm{HCl} \mathrm{solution.}$ Mater. Today Commun. 2021, 27, 102249. [CrossRef] 
30. Saeed, M.; Saleem, M.; Usmani, S.; Malik, I.A.; Al-Shammari, F.A.; Deen, K.M. Corrosion inhibition of mild steel in 1 M HCl by sweet melon peel extract. J. King Saud Univ. Sci. 2019, 31, 1344-1351. [CrossRef]

31. Fadare, O.; Okoronkwo, A.E.; Olasehinde, E.F. Assessment of anti-corrosion potentials of extract of Ficus asperifolia -Miq (Moraceae) on mild steel in acidic medium. Afr. J. Pure Appl. Chem. 2016, 10, 8-22. [CrossRef]

32. Sakunthala, P.; Vivekananthan, S.S.; Gopiraman, M.; Sulochana, N.; Vincent, A.R. Spectroscopic investigations of physicochemical interactions on Umoren mild steel in an acidic medium by environmentally friendly green inhibitors. J. Surfactants Deterg. 2013, 16, 251-263. [CrossRef]

33. Rani, B.E.A.; Basu, B.B.J. Green Inhibitors for Corrosion Protection of Metals and Alloys: An Overview. Int. J. Corros. 2011, 2012, 380217. [CrossRef]

34. Lipinski, B. Hydroxyl Radical and Its Scavengers in Health and Disease. Oxidative Med. Cell. Longev. 2011, 2011, 809696. [CrossRef]

35. Kumar, T.; Jain, V. Appraisal of total phenol, flavonoid contents, and antioxidant potential of folkloric Lannea coromandelica using in vitro and in vivo assays. Scientifica 2015, 2015, 203679. [CrossRef]

36. Chaouche, T.M.; Haddouchi, F.; Ksouri, R.; Atik-Bekkara, F. Evaluation of antioxidant activity of hydromethanolic extracts of some medicinal species from South Algeria. J. Chin. Med. Assoc. 2014, 77, 302-307. [CrossRef] [PubMed]

37. Zhang, J.; Song, Y.; Su, H.; Zhang, L.; Chen, G.; Zhao, J. Investigation of Diospyros Kaki L. f husk extracts as corrosion inhibitors and bactericide in oil field. Chem. Central J. 2013, 7, 109. [CrossRef] [PubMed]

38. Pandey, K.B.; Rizvi, S.I. Plant Polyphenols as Dietary Antioxidants in Human Health and Disease. Oxidative Med. Cell. Longev. 2009, 2, 270-278. [CrossRef] [PubMed]

39. Fraga, C.G.; Galleano, M.; Verstraeten, S.; Oteiza, P.I. Basic biochemical mechanisms behind the health benefits of polyphenols. Mol. Asp. Med. 2010, 31, 435-445. [CrossRef]

40. Gangwar, M.; Gautam, M.K.; Sharma, A.K.; Tripathi, Y.B.; Goel, R.K.; Nath, G. Antioxidant Capacity and Radical Scavenging Effect of Polyphenol RichMallotus philippenensisFruit Extract on Human Erythrocytes: AnIn VitroStudy. Sci. World J. 2014, 2014, 279451. [CrossRef]

41. Liang, N.; Kitts, D.D. Antioxidant Property of Coffee Components: Assessment of Methods that Define Mechanisms of Action. Molecules 2014, 19, 19180-19208. [CrossRef]

42. Habu, J.B.; Ibeh, B.O. In vitro antioxidant capacity and free radical scavenging evaluation of active metabolite constituents of Newbouldia laevis ethanolic leaf extract. Biol. Res. 2015, 48, 16. [CrossRef] [PubMed]

43. Boora, F.; Chirisa, E.; Mukanganyama, S. Evaluation of Nitrite Radical Scavenging Properties of Selected Zimbabwean Plant Extracts and Their Phytoconstituents. J. Food Process. 2014, 2014, 918018. [CrossRef]

44. Zhao, H.-X.; Zhang, H.-S.; Yang, S.-F. Phenolic compounds and its antioxidant activities in ethanolic extracts from seven cultivars of Chinese jujube. Food Sci. Hum. Wellness 2014, 3, 183-190. [CrossRef]

45. Do, Q.D.; Angkawijaya, A.E.; Tran-Nguyen, P.L.; Huynh, L.H.; Soetaredjo, F.E.; Ismadji, S.; Ju, Y.H. Effect of extraction solvent on total phenol content, total flavonoid content, and antioxidant activity of Limnophila aromatica. J. Food Drug. Anal. 2014, 22, 296-302. [CrossRef] [PubMed]

46. Prabakaran, M.; Kim, S.-H.; Sasireka, A.; Chandrasekaran, M.; Chung, I.-M. Polyphenol composition and antimicrobial activity of various solvent extracts from different plant parts of Moringa oleifera. Food Biosci. 2018, 26, 23-29. [CrossRef]

47. Chung, I.-M.; Malathy, R.; Priyadharshini, R.; Hemapriya, V.; Kim, S.-H.; Prabakaran, M. Inhibition of mild steel corrosion using Magnolia kobus extract in sulphuric acid medium. Mater. Today Commun. 2020, 25, 101687. [CrossRef]

48. Manokarana, G.; Prabakaran, M. Evaluation of antioxidant and anticorrosion activities of Ligularia fischeri plant extract. Chem. Sci. Eng. Res. 2019, 1, 16-24. [CrossRef]

49. Chung, I.-M.; Kim, S.-H.; Prabakaran, M. Evaluation of Phytochemical, Polyphenol Composition and Anti-corrosion Capacity of Cucumis anguria L. Leaf Extract on Metal Surface in Sulfuric Acid Medium. Prot. Met. Phys. Chem. Surf. 2020, 56, 214-224. [CrossRef]

50. Nahlé, A.; Abu-Abdoun, I.; Abdel-Rahman, I. Effect of Temperature on the Corrosion Inhibition of Trans-4-Hydroxy-4'-Stilbazole on Mild Steel in HCl Solution. Int. J. Corros. 2012, 2012, 380329. [CrossRef]

51. Labjar, N.; Bentiss, F.; Lebrini, M.; Jama, C.; El Hajjaji, S. Study of Temperature Effect on the Corrosion Inhibition of C38 Carbon Steel Using Amino-tris(Methylenephosphonic) Acid in Hydrochloric Acid Solution. Int. J. Corros. 2011, 2011, 548528. [CrossRef]

52. Umoren, S.; Eduok, U.; Solomon, M.; Udoh, A. Corrosion inhibition by leaves and stem extracts of Sida acuta for mild steel in 1M H2SO4 solutions investigated by chemical and spectroscopic techniques. Arab. J. Chem. 2016, 9, S209-S224. [CrossRef]

53. Júnior, J.M.F.; Silva, M.G.D.; Monteiro, J.A.; Barros, A.D.S.; Falcão, M.J.C.; Morais, S.M.D. Evaluation of antioxidant activity and inhibition of corrosion by brazilian plant extracts and constituents. Int. J. Electrochem. Sci. 2016, 11, 3862-3875. [CrossRef]

54. Hassan, H.M. Utility of bacterial biomass as antioxidant, anticorrosive, and antifriction additives for lubricating oils. Petrol Sci. Technol. 2011, 29, 2086-2094. [CrossRef]

55. Prabakaran, M.; Kim, S.-H.; Kalaiselvi, K.; Hemapriya, V.; Chung, I.-M. Highly efficient Ligularia fischeri green extract for the protection against corrosion of mild steel in acidic medium: Electrochemical and spectroscopic investigations. J. Taiwan Inst. Chem. Eng. 2016, 59, 553-562. [CrossRef]

56. Prabakaran, M.; Kim, S.-H.; Hemapriya, V.; Chung, I.-M. Tragia plukenetii extract as an eco-friendly inhibitor for mild steel corrosion in $\mathrm{HCl} 1 \mathrm{M}$ acidic medium. Res. Chem. Intermed. 2015, 42, 3703-3719. [CrossRef] 
57. Dehghani, A.; Bahlakeh, G.; Ramezanzadeh, B.; Ramezanzadeh, M. A combined experimental and theoretical study of green corrosion inhibition of mild steel in $\mathrm{HCl}$ solution by aqueous Citrullus lanatus fruit (CLF) extract. J. Mol. Liq. 2019, $279,603-624$. [CrossRef]

58. Taheri, S.; Delgado, G.P.; Agbaje, O.B.A.; Giri, P.; Clark, S.M. Corrosion inhibitory effects of mullite in concrete exposed to sulfuric acid attack. Corros. Mater. Degrad. 2020, 1, 282-295. [CrossRef]

59. Baran, E.; Cakir, A.; Yazici, B. Inhibitory effect of Gentiana olivieri extracts on the corrosion of mild steel in $0.5 \mathrm{M} \mathrm{HCl:} \mathrm{Electro-}$ chemical and phytochemical evaluation. Arab. J. Chem. 2016, 12, 4303-4319. [CrossRef]

60. Patni, N.; Agarwal, S.; Shah, P. Greener Approach towards Corrosion Inhibition. Chin. J. Eng. 2013, 2013, 784186. [CrossRef]

61. Chitra, S.; Chung, I.-M.; Kim, S.-H.; Prabakaran, M. A study on anticorrosive property of phenolic components from Pachysandra terminalis against low carbon steel corrosion in acidic medium. Pigment Resin Technol. 2019, 48, 389-396. [CrossRef]

62. Chung, I.-M.; Hemapriya, V.; Kim, S.-H.; Ponnusamy, K.; Arunadevi, N.; Chitra, S.; Prabakaran, M.; Gopiraman, M. Liriope platyphylla extract as a green inhibitor for mild steel corrosion in sulfuric acid medium. Chem. Eng. Commun. 2019, 208, 72-88. [CrossRef]

63. Mahalakshmi, D.; Unnisa, C.B.N.; Hemapriya, V.; Subramaniam, E.P.; Roopan, S.M.; Chitra, S.; Chung, I.M.; Kim, S.H.; Prabakaran, M. Anticorrosive potential of ethanol extract of Delonix elata for mild steel in $0.5 \mathrm{M} \mathrm{H}_{2} \mathrm{SO}_{4}-\mathrm{A}$ green approach, Bulg. Chem. Commun. 2019, 51, 31-37.

64. Chung, I.-M.; Malathy, R.; Kim, S.-H.; Kalaiselvi, K.; Prabakaran, M.; Gopiraman, M. Ecofriendly green inhibitor from Hemerocallis fulva against aluminum corrosion in sulphuric acid medium. J. Adhes. Sci. Technol. 2020, 34, 1483-1506. [CrossRef]

65. Hemapriya, V.; Prabakaran, M.; Chitra, S.; Swathika, M.; Kim, S.-H.; Chung, I.-M. Utilization of biowaste as an eco-friendly biodegradable corrosion inhibitor for mild steel in $1 \mathrm{~mol} / \mathrm{L} \mathrm{HCl}$ solution. Arab. J. Chem. 2020, 13, 8684-8696. [CrossRef]

66. Anitha, R.; Unnisa, C.B.N.; Hemapriya, V.; Roopan, S.M.; Chitra, S.; Chung, I.-M.; Kim, S.-H.; Mayakrishnan, P. Anti-corrosive potential of Cyperus rotundus as a viable corrosion inhibitor for mild steel in sulphuric acid. Pigment Resin Technol. 2020, 49, 295-304. [CrossRef]

67. Al-Amiery, A.A.; Ahmed, M.H.O.; Abdullah, T.A.; Gaaz, T.S.; Kadhum, A.A.H. Electrochemical studies of novel corrosion inhibitor for mild steel in $1 \mathrm{M}$ hydrochloric acid. Results Phys. 2018, 9, 978-981. [CrossRef]

68. Chung, I.-M.; Kim, S.-H.; Hemapriya, V.; Kalaiselvi, K.; Prabakaran, M. Inhibition behavior of Tragia involucrata L. phenolic compounds against acidic medium corrosion in low carbon steel surface. Chin. J. Chem. Eng. 2018, 27, 717-725. [CrossRef]

69. Chung, I.-M.; Hemapriya, V.; Ponnusamy, K.; Arunadevi, N.; Chitra, S.; Youn, C.-H.; Kim, S.-H.; Prabakaran, M. Assessment of Low Carbon Steel Corrosion Inhibition by Eco-Friendly Green Chaenomeles sinensis Extract in Acid Medium. J. Electrochem. Sci. Technol. 2018, 9, 238-249. [CrossRef]

70. Prabakaran, M.; Kim, S.H.; Hemapriya, V.; Gopiraman, M.; Kim, I.S.; Chung, I.M. Rhus verniciflua as a green corrosion inhibitor for mild steel in $1 \mathrm{M} \mathrm{H}_{2} \mathrm{SO}_{4}$. RSC Adv. 2016, 6, 57144-57153. [CrossRef]

71. Anitha, R.; Chitra, S.; Hemapriya, V.; Chung, I.-M.; Kim, S.-H.; Prabakaran, M. Implications of eco-addition inhibitor to mitigate corrosion in reinforced steel embedded in concrete. Constr. Build. Mater. 2019, 213, 246-256. [CrossRef]

72. Ostovari, A.; Hoseinieh, S.M.; Peikari, M.P.; Shadizadeh, S.R.; Hashemi, J. Corrosion inhibition of mild steel in $1 \mathrm{M} \mathrm{HCl} \mathrm{solution}$ by henna extract: A comparative study of the inhibition by henna and its constituents (Lawsone, Gallic acid, alpha-D-Glucose and Tannic acid). Corros. Sci. 2009, 51, 1935-1949. [CrossRef]

73. Leena, P.; Hukuman, N.H.Z.; Biju, A.R.; Jisha, M. Studies on methanolic extract of Lepidagathis keralensis as green corrosion inhibitor for mild steel in 1M HCl. J. Electrochem. Sci. Technol. 2019, 10, 231-243.

74. Ramezanzadeh, M.; Bahlakeh, G.; Sanaei, Z.; Ramezanzadeh, B. Corrosion inhibition of mild steel in $1 \mathrm{M} H C l$ solution by ethanolic extract of eco-friendly Mangifera indica (mango) leaves: Electrochemical, molecular dynamics, Monte Carlo and ab initio study. Appl. Surf. Sci. 2019, 463, 1058-1077. [CrossRef]

75. Bouyanzer, A.; Hammouti, B.; Majidi, L. Pennyroyal oil from Mentha pulegium as corrosion inhibitor for steel in 1M HCl. Mater. Lett. 2006, 60, 2840-2843. [CrossRef]

76. Benarioua, M.; Mihi, A.; Bouzeghaia, N.; Naoun, M. Mild steel corrosion inhibition by Parsley (Petroselium Sativum) extract in acidic media. Egypt. J. Pet. 2019, 28, 155-159. [CrossRef] 